\title{
IMPACT OF SUPPORT CLOSED SECTION RIBS ON THE CRITICAL MOMENT FOR LATERAL TORSIONAL BUCKLING OF STEEL BEAMS
}

\section{WPŁYW ŻEBER PODPOROWYCH O PRZEKROJU ZAMKNIĘTYM NA MOMENT KRYTYCZNY ZWICHRZENIA BELEK STALOWYCH}

DOI: $10.30540 /$ sae-2018-001

\begin{abstract}
The study presents the results of theoretical investigations into the effect produced by support closed section ribs on the critical moment for lateral torsional buckling (Mcr) of bisymmetric I-beams. Elastic restraint against warping, at the site of support, was provided by closed section ribs made from selected rolled profiles (longitudinally cut circular tubes, angles, and channels). Detailed calculations were made for beams under uniform load applied to the top flange of the section. The results obtained in the investigations were compared with the values obtained for beams with end plate. The analysis was conducted of the impact of ribs on the increase in the critical resistance of beams. Analytically estimated critical moments for lateral torsional buckling were verified using FEM tools (LTBeamN, Abaqus).
\end{abstract}

Keywords: critical moment for lateral torsional buckling, closed section ribs, elastic restraint against warping

\section{Streszczenie}

W pracy przedstawiono wyniki badań teoretycznych wptywu podporowych żeber zamkniętych na moment krytyczny zwichrzenia (Mcr) belek o bisymetrycznym przekroju dwuteowym. Sprężyste zamocowanie przeciw spaczeniu w miejscu podparcia stanowity żebra o przekroju zamkniętym, które wykonano z wybranych profili walcowanych (podhużnie rozcięte rury, kątowniki, ceowniki). Obliczenia szczegótowe wykonano dla belek obciażonych równomiernie obciażeniem przytożonym do pótki górnej przekroju. Uzyskane wyniki porównano z wartościami otrzymanymi dla belek z żebrowaniem w postaci blachy czolowej. Przeprowadzono analizę wplywu żeber na zwiększenie nośności krytycznej belek. Oszacowane analitycznie momenty krytyczne zwichrzenia zweryfikowano za pomoca MES (LTBeamN, Abaqus).

Słowa kluczowe: moment krytyczny zwichrzenia, żebra o przekroju zamkniętym, sprężyste zamocowanie przeciw spaczeniu

\section{Introduction}

One of the methods for increasing the critical resistance of steel beams, which results from lateral torsional buckling condition, is the use of support ribs that confine the warping of the section. Different types of ribs are used to this end [7]. The advantages offered by the use of closed section ribs were reported, among others, by Kowal [1, 5], Trahair [7], and Gosowski [3, 4]. Ribs of that type show high torsional stiffness in the plane of the section flanges. Stiff connections of ribs to beam flanges and to the web considerably restrain the possibility of the rotation of flanges relative to each other. Such a significant reduction in beam section warping

\section{Wprowadzenie}

Jedną z metod zwiększania nośności krytycznej belek stalowych z warunku zwichrzenia jest zastosowanie żeber podporowych ograniczających spaczenie przekroju. W tym celu stosuje się różne typy żebrowania [7]. O korzyściach związanych z zastosowaniem żeber o przekroju zamkniętym pisali m.in. Kowal $[1,5]$, Trahair [7], Gosowski [3, 4]. Żebra tego typu charakteryzują się dużą sztywnością na skręcanie w płaszczyźnie półek przekroju. Sztywne połączenie żeber z półkami oraz środnikiem belki znacznie ogranicza możliwość obrotu półek względem siebie. Tak istotna redukcja spaczenia (deplanacji) przekroju belki w miejscu występowania żebra zamkniętego 
(deplanation) at the site of closed section rib location produces an increase in the critical moment $\left(M_{c r}\right)$ for lateral torsional buckling (LTB). Experimental investigations (e.g. [4]) and numerical calculations with the use of FEM (e.g. [7]) confirmed an increase in the critical load of beams stiffened with closed section ribs. However, other types of ribs used at beam supports (e.g. end plate, ribs parallel to the web, N- or X-shaped ribs), which were reported, e.g. in studies [1-4, 6-8], confine section warping to a far lesser extent. The most common stiffener is the end plate, which is used both in simply supported beams [6-8] and also in beam connections to other structural members (e.g. columns) [2]. The stiffening of support sections with flexible double sided rib is also applied [9]. However, much lower increase in $M_{c r}$ is received compared with closed section ribs.

From the technological standpoint, closed section ribs can be obtained using rolled shapes (e.g. longitudinally cut circular tubes, angles or channels) that are welded on both sides (to the web and flanges), as shown, e.g., in Figure 1.
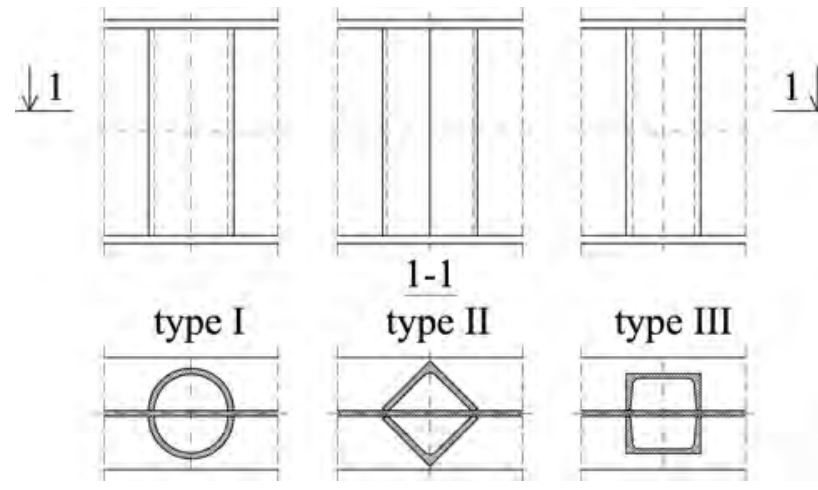

This study analyses the impact of the support ribs with different closed sections on the critical moment for LTB. The analysis covered simply supported I-beams with bisymmetric section (IPE300, IPE500, and also HEA300 and HEA500), elastically restrained against warping at the support nodes and uniformly loaded at the top flange level. Computations were performed for a few types of closed section ribs. The results were compared with those for commonly used end plate stiffeners. The selection of closed section ribs was based on the geometry of beam shapes (the height of the web and the width of flanges). Critical moments for LTB were estimated by means of the approximation formula acc. study [8]. Computations were validated by comparison with FEM results (LTBeamN, Abaqus). daje wzrost momentu krytycznego zwichrzenia $\left(M_{c r}\right)$. Zwiększenie obciążenia krytycznego belek usztywnionych żebrami zamkniętymi potwierdzono badaniami doświadczalnymi (np. [4]) oraz obliczeniami numerycznymi z wykorzystaniem MES (np. [7]). Natomiast zastosowanie innego typu żebrowania belek na podporach (np. blacha czołowa, żebra równoległe do środnika, żebra w kształcie litery N lub X), które zaproponowano m.in. w pracach [1-4, 6-8], w zdecydowanie mniejszym stopniu ogranicza spaczenie przekroju. Najczęściej występującym usztywnieniem jest blacha czołowa, która jest stosowana zarówno w belkach swobodnie podpartych [6-8], jak również $\mathrm{w}$ doczołowych połączeniach belek $\mathrm{z}$ innymi elementami konstrukcji (np. słupami) [2]. Stosuje się również usztywnienie przekrojów podporowych obustronnym żebrem podatnym [9]. Jednakże w tych przypadkach uzyskuje się znacznie mniejszy wzrost $M_{c r}$ W stosunku do żeber o przekroju zamkniętym.

$\mathrm{Z}$ technologicznego punktu widzenia żebra o przekroju zamkniętym można uzyskać, spawając obustronnie (do środnika i półek) kształtowniki walcowane (np. podłużnie rozcięte rury, kątowniki lub ceowniki), np. według rysunku 1 .

Fig. 1. Types of closed ribs: I - circular tubes (Ø), II angles (2L), III-channels (2C)

Rys. 1. Typy żeber o przekroju zamkniętym: I - rura (Ø), II - katowniki (2L), III - ceowniki (2C)

W niniejszej pracy przeanalizowano wpływ żeber podporowych o różnych przekrojach zamkniętych na moment krytyczny zwichrzenia. Badano swobodnie podparte belki dwuteowe o przekroju bisymetrycznym (IPE300 i IPE500 oraz HEA300 i HEA500), sprężyście zamocowane przeciw spaczeniu $\mathrm{w}$ węzłach podporowych i obciążone równomiernie w poziomie półki górnej. Obliczenia przeprowadzono dla kilku wariantów żeber o przekroju zamkniętym. Wyniki porównano z powszechnie stosowanym żebrowaniem w postaci blachy czołowej. Podczas doboru przekrojów żeber zamkniętych kierowano się geometrią kształtowników belek (tzn. wysokością środnika i szerokością półek). Momenty krytyczne zwichrzenia oszacowano wzorem aproksymacyjnym według pracy [8]. Obliczenia zweryfikowano za pomocą MES (LTBeamN, Abaqus). 


\section{Critical moment for lateral torsional buckling of the beam elastically restrained against warping}

Critical moment for LTB of the beam (Fig. 2), bilaterally elastically restrained against warping at supports, can be estimated with formula (1) put forward in study [8]:

$$
M_{c r}=\frac{-B_{1} E I_{z} z_{g}+\sqrt{E I_{z}\left(B_{3} G I_{t} L^{2}+B_{4} E I_{\omega}+B_{1}^{2} E I_{z} z_{g}^{2}\right)}}{B_{2} L^{2}}
$$

where: $I_{z}, I_{t}, I_{\omega}$ - beam section characteristics, $L$ - beam span (Fig. 2), $B_{1}, B_{2}, B_{3}, B_{4}$ - coefficients (Table 1$), z_{g}$ - ordinate of the load application site (Fig. 2).

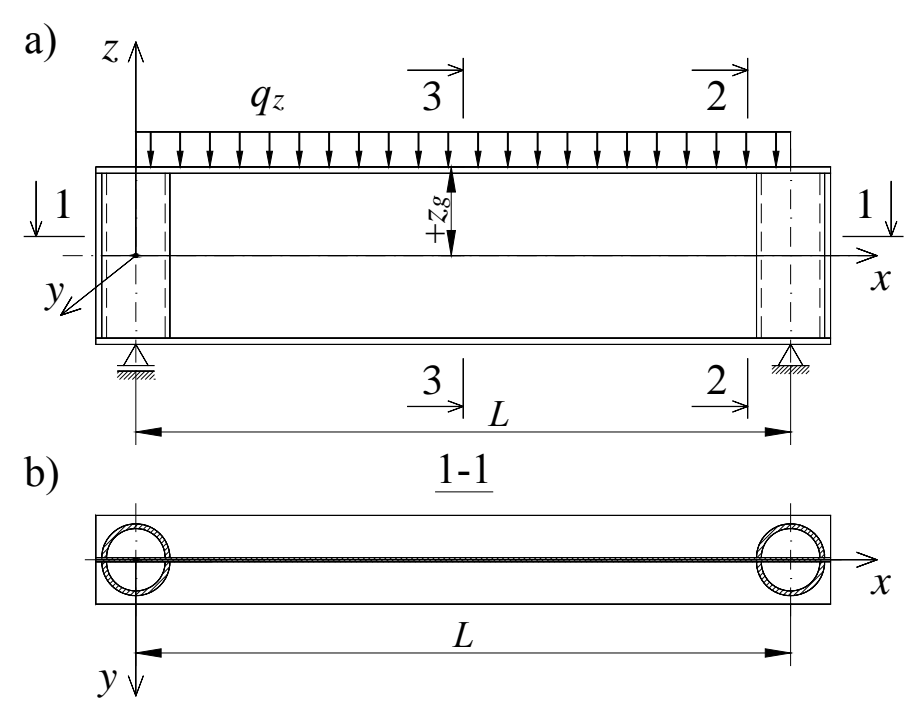

b)

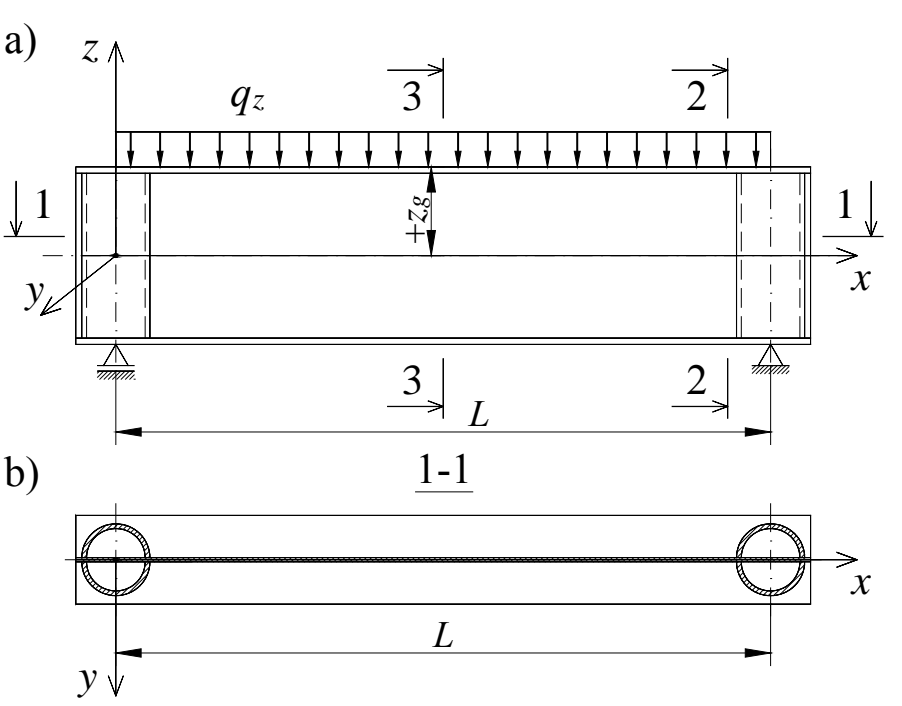

\section{Moment krytyczny zwichrzenia belki sprężyście zamocowanej przeciw spaczeniu}

Moment krytyczny zwichrzenia belki (rys. 2), obustronnie sprężyście zamocowanej przeciw spaczeniu na podporach, można oszacować za pomocą wzoru (1) zaproponowanego w pracy [8]:

$$
M_{c r}=\frac{-B_{1} E I_{z} z_{g}+\sqrt{E I_{z}\left(B_{3} G I_{t} L^{2}+B_{4} E I_{\omega}+B_{1}^{2} E I_{z} z_{g}^{2}\right)}}{B_{2} L^{2}}
$$

gdzie: $I_{z}, I_{t}, I_{\omega}$ - charakterystyki przekroju belki, $L$ - rozpiętość belki (rys. 2), $B_{1}, B_{2}, B_{3}, B_{4}$ - współczynniki (tab. 1), $z_{g}$ - rzędna miejsca przyłożenia obciążenia (rys. 2).

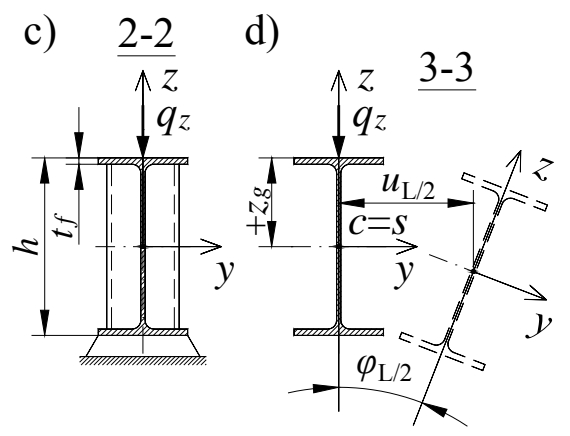

Fig. 2. Geometry and static beam diagram (a), section 1-1 (b), section 2-2 (c), section 3-3 (d)

Rys. 2. Geometria i schemat statyczny belki (a), przekrój 1-1 (b), przekrój 2-2 (c), przekrój 3-3(d)

Degree of the elastic restraint against warping, which results from the action of support ribs, was expressed by a dimensionless index of fixity $\kappa(2)$ acc. [8], which ranges from $\kappa=0$ for complete warping freedom, to $\kappa=1$ for complete warping restraint:

$$
\kappa=\frac{\alpha_{\omega} L}{2 E_{\omega}+\alpha_{\omega} L}
$$

where: $\alpha_{\omega}$ - stiffness of the elastic restraint against warping, which is expressed by formula (3) acc. [7]:

$$
\alpha_{\omega}=-\frac{B}{\frac{d \varphi}{d x}}=G I_{d} h_{0}
$$

where: $I_{d}$ - torsional moment of inertia of the whole rib section (Table 2), $h_{0}=h-t_{f}$ - theoretical height of ribs (see Fig. 2).
Stopień sprężystego zamocowania przeciw spaczeniu, wynikający z oddziaływania żeber podporowych, wyrażono bezwymiarowym wskaźnikiem utwierdzenia $\kappa$ (2) według [8], zmieniającym się od $\kappa=0$, dla pełnej swobody spaczenia, do $\kappa=1$, dla pełnej blokady spaczenia:

$$
\kappa=\frac{\alpha_{\omega} L}{2 E_{\omega}+\alpha_{\omega} L}
$$

gdzie: $\alpha_{\omega}$ - sztywność sprężystego zamocowania przeciw spaczeniu, którą określono wzorem (3) [7]:

$$
\alpha_{\omega}=-\frac{B}{\frac{d \varphi}{d x}}=G I_{d} h_{0}
$$

gdzie: $I_{d}$ - moment bezwładności na skręcanie całego przekroju żebra (tabela 2), $h_{0}=h-t_{f}$ - teoretyczna wysokość żebra (por. rys. 2). 
Table 1. Coefficients $B_{1}, B_{2}, B_{3}, B_{4}[8]$

Tabela 1. Współczynniki $B_{1}, B_{2}, B_{3}, B_{4}[8]$

\begin{tabular}{|c|c|c|c|}
\hline Item & Loading diagram & \multicolumn{2}{|c|}{ Coefficients } \\
\hline 1. & 2. & \multicolumn{2}{|l|}{3.} \\
\hline \multirow{2}{*}{1.} & $P_{z}$ & $B_{1}=7.242 \cdot\left(1.563-2.5 \kappa+\kappa^{2}\right)$ & $B_{2}=1.522-2.467 \kappa+\kappa^{2}$ \\
\hline & $L \quad \quad-$ & $B_{3}=19.248 \cdot B_{2}\left(1.457-2.4 \kappa+\kappa^{2}\right)$ & $B_{4}=231.816 \cdot B_{2}(1.2-\kappa)$ \\
\hline \multirow{2}{*}{2.} & 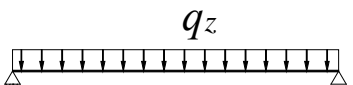 & $B_{1}=5.25 \cdot\left(1.476-2.429 \kappa+\kappa^{2}\right)$ & $B_{2}=1.507-2.455 \kappa+\kappa^{2}$ \\
\hline & $-\quad L$ & $B_{3}=13.092 \cdot B_{2}\left(1.457-2.4 \kappa+\kappa^{2}\right)$ & $B_{4}=157.633 \cdot B_{2}(1.2-\kappa)$ \\
\hline \multirow{2}{*}{3.} & $\begin{array}{l}q_{z} \\
T+1+T T\end{array}$ & $B_{1}=5.322 \cdot\left(1.476-2.429 \kappa+\kappa^{2}\right)$ & $B_{2}=1.507-2.455 \kappa+\kappa^{2}$ \\
\hline & $L$ & $B_{3}=13.624 \cdot B_{2}\left(1.457-2.4 \kappa+\kappa^{2}\right)$ & $B_{4}=163.486 \cdot B_{2}(1.2-\kappa)$ \\
\hline
\end{tabular}

\section{Types of support ribs}

Table 2 shows types of support ribs considered in the analysis (row 1) and formulas for their torsional moments of inertia $I_{d}$ (row 2).

\section{Typy żeber podporowych}

$\mathrm{W}$ tabeli 2 zamieszczono przyjęte $\mathrm{w}$ analizie typy żeber podporowych (wiersz 1) oraz wzory na ich momenty bezwładności na skręcanie $I_{d}$ (wiersz 2).

Table 2. Types of ribs included in the analysis

Tabela 2. Typy żeber uwzględnione $w$ analizie

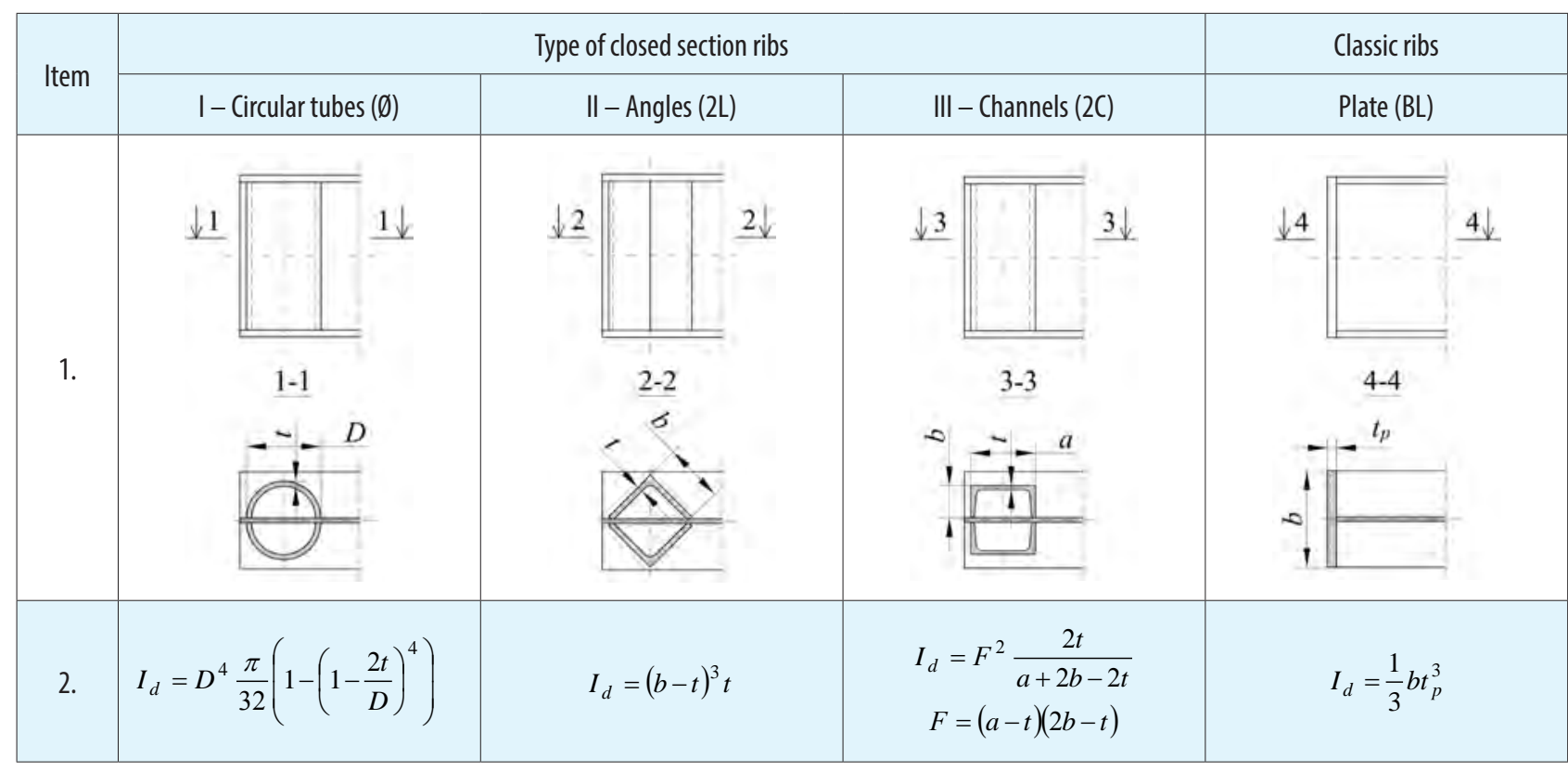

The types of ribs (I, II and III) that were identified were classified into three groups (1,2 and 3$)$ on the basis of the beam section geometry and the "diameter" of the rib sections. Basic adjustment of selected shapes $(\varnothing, 2 \mathrm{~L}, 2 \mathrm{C})$ to individual groups is presented in Table 3.
Wyróżnione typy żeber (I, II i III) sklasyfikowano w trzech grupach (1, 2 i 3$)$ w zależności od geometrii przekroju belki oraz ,średnicy” przekroju żebra. Podstawowe przyporządkowanie dobranych kształtowników (Ø, 2L, 2C) do poszczególnych grup zamieszczono w tabeli 3. 
Table 3. Assignment of selected sections of rib types (I, II and III) to groups (1, 2 and 3)

Tabela 3. Przyporzadkowanie dobranych ksztaltowników żeber w ramach typów (I, II i III) do grup (1, 2 i 3)

\begin{tabular}{|c|c|c|c|c|}
\hline \multirow{2}{*}{ Profile } & \multicolumn{4}{|c|}{ Type of closed section ribs } \\
\hline & Group & I- Circular tubes $(\emptyset)$ & II - Angles (2L) & III - Channels (2C) \\
\hline IPE300 & 1 & $\emptyset 127.0 / 10$ & 2L90x10 & $2 C 140$ \\
\hline IPE500 & 2 & $\emptyset 177.8 / 10$ & 2L120x10 & $2 C 180$ \\
\hline $\begin{array}{l}\text { HEA300 } \\
\text { HEA500 }\end{array}$ & 3 & $\emptyset 273.0 / 10$ & 2L180x16 & $2 C 300$ \\
\hline
\end{tabular}

Additionally, for larger sections, i.e. IPE500, HEA300 and HEA500, comparative calculations were made. That was done relative to ribs of group 1, which had a smaller "diameter" (Table 3).

Table 4 lists values $I_{d}$ determined acc. Table 2, and stiffnesses $\alpha_{\omega}$ acc. formula (3) [7] for the sections analysed, and also types and groups of ribs (see Table 3 ). For the sake of comparison, column 6 (Table 4) features corresponding characteristics when support sections were stiffened by means of classic end plate with the thickness of $t_{p}$.

Table 4. Characteristics of the ribs included in the analysis Tabela 4. Charakterystyki przyjętych $w$ analizie żeber
Ponadto dla przekrojów „większych”, tzn. IPE500 oraz HEA300 i HEA500, wykonano również obliczenia porównawcze $\mathrm{z}$ zastosowaniem grupy 1 żeber o mniejszej ,średnicy” według tabeli 3.

W tabeli 4 podano wartości $I_{d}$, wyznaczone według tabeli 2, oraz sztywności $\alpha_{\omega}$, według wzoru (3) [7] dla analizowanych przekrojów i przyjętych typów i grup żeber (por. tabelę 3). Dla porównania, w kolumnie 6 (tabela 4) podano odpowiednie charakterystyki dla usztywnienia przekrojów podporowych klasyczną blachą czołową o grubości $t_{p}$.

\begin{tabular}{|c|c|c|c|c|c|}
\hline \multirow{2}{*}{ Profile } & \multicolumn{4}{|c|}{ Types of closed section ribs } & \multirow{2}{*}{$\begin{array}{c}\text { Classic ribs } \\
\text { End plate (BL) }\end{array}$} \\
\hline & Group & I - Circular tube (Ø) & II - Angles (2L) & III - Channels (2C) & \\
\hline 1. & 2. & 3. & 4. & 5. & 6. \\
\hline $\begin{array}{l}\text { 怘 } \\
\underline{\underline{\underline{I}}}\end{array}$ & 1. & $\begin{array}{c}\emptyset 127.0 / 10 \\
I_{d}=1267 \mathrm{~cm}^{4} \\
a_{\omega}=297 \mathrm{kNm}^{3} / \mathrm{rad}\end{array}$ & $\begin{array}{c}2 L 90 \times 10 \\
I_{d}=512 \mathrm{~cm}^{4} \\
a_{\omega}=120 \mathrm{kNm}^{3} / \mathrm{rad}\end{array}$ & $\begin{array}{c}26140 \\
l_{d}=1285 \mathrm{~cm}^{4} \\
a_{\omega}=301 \mathrm{kNm}^{3} / \mathrm{rad}\end{array}$ & $\begin{array}{c}t_{p}=16 \mathrm{~mm} \\
l_{d}=20 \mathrm{~cm}^{4} \\
a_{\omega}=5 \mathrm{kNm}^{3} / \mathrm{rad}\end{array}$ \\
\hline \multirow[b]{2}{*}{$\begin{array}{l}\text { 总 } \\
\text { 을 }\end{array}$} & 1. & $a_{\omega}=497 \mathrm{kNm}^{3} / \mathrm{rad}$ & $a_{\omega}=201 \mathrm{kNm}^{3} / \mathrm{rad}$ & $a_{\omega}=504 \mathrm{kNm}^{3} / \mathrm{rad}$ & \multirow[b]{2}{*}{$\begin{array}{c}t_{p}=20 \mathrm{~mm} \\
l_{d}=53 \mathrm{~cm}^{4} \\
a_{\omega}=21 \mathrm{kNm}^{3} / \mathrm{rdd}\end{array}$} \\
\hline & 2. & $\begin{array}{c}\emptyset 177.8 / 10 \\
I_{d}=3722 \mathrm{~cm}^{4} \\
a_{\omega}=1459 \mathrm{kNm}^{3} / \mathrm{rad}\end{array}$ & $\begin{array}{c}2 \mathrm{~L} 120 \times 10 \\
I_{d}=1331 \mathrm{~cm}^{4} \\
a_{\omega}=522 \mathrm{kNm}^{3} / \mathrm{rad}\end{array}$ & $\begin{array}{c}2 C 180 \\
l_{d}=2713 \mathrm{~cm}^{4} \\
a_{\omega}=1064 \mathrm{kNm}^{3} / \mathrm{rad}\end{array}$ & \\
\hline \multirow[b]{2}{*}{$\begin{array}{l}\text { ᄋે } \\
\text { 室 }\end{array}$} & 1 & $a_{\omega}=283 \mathrm{kNm}^{3} / \mathrm{rad}$ & $a_{\omega}=114 \mathrm{kNm}^{3} / \mathrm{rad}$ & $a_{\omega}=287 \mathrm{kNm}^{3} / \mathrm{rad}$ & \multirow[b]{2}{*}{$\begin{array}{c}t_{p}=20 \mathrm{~mm} \\
l_{d}=80 \mathrm{~cm}^{4} \\
a_{\omega}=18 \mathrm{kNm}^{3} / \mathrm{rad}\end{array}$} \\
\hline & 3. & $\begin{array}{c}\emptyset 273.0 / 10 \\
l_{d}=14301 \mathrm{~cm}^{4} \\
a_{\omega}=3197 \mathrm{kNm}^{3} / \mathrm{rad}\end{array}$ & $\begin{array}{c}2 \mathrm{~L} 180 \times 16 \\
I_{d}=7058 \mathrm{~cm}^{4} \\
a_{\omega}=1578 \mathrm{kNm}^{3} / \mathrm{rad}\end{array}$ & $\begin{array}{c}26300 \\
l_{d}=12650 \mathrm{~cm}^{4} \\
a_{\omega}=2828 \mathrm{kNm}^{3} / \mathrm{rad}\end{array}$ & \\
\hline \multirow[b]{2}{*}{$\begin{array}{l}\text { 吕 } \\
\text { 䚾 }\end{array}$} & 1. & $a_{\omega}=479 \mathrm{kNm}^{3} / \mathrm{rad}$ & $a_{\omega}=194 \mathrm{kNm}^{3} / \mathrm{rad}$ & $a_{\omega}=486 \mathrm{kNm}^{3} / \mathrm{rad}$ & \multirow{2}{*}{$\begin{array}{c}t_{p}=25 \mathrm{~mm} \\
l_{d}=156 \mathrm{~cm}^{4} \\
a_{\omega}=59 \mathrm{kNm}^{3} / \mathrm{rad}\end{array}$} \\
\hline & 3. & $\begin{array}{c}\emptyset 273.0 / 10 \\
I_{d}=14301 \mathrm{~cm}^{4} \\
a_{\omega}=5410 \mathrm{kNm}^{3} / \mathrm{rad}\end{array}$ & $\begin{array}{c}2 \mathrm{~L} 180 \times 16 \\
I_{d}=7058 \mathrm{~cm}^{4} \\
a_{\omega}=2670 \mathrm{kNm}^{3} / \mathrm{rad}\end{array}$ & $\begin{array}{c}2 C 300 \\
I_{d}=12650 \mathrm{~cm}^{4} \\
a_{\omega}=4785 \mathrm{kNm}^{3} / \mathrm{rad}\end{array}$ & \\
\hline
\end{tabular}

In order to determine $M_{c r}$ acc. (1), it is necessary to correctly determine stiffnesses of the elastic restraint $\alpha_{\omega}$ (3) and indexes of fixity $\kappa$ (2) for the rib type and group. The computations were made using spreadsheet.
W celu wyznaczenia $M_{c r}$ wg wzoru (1) należy poprawnie wyznaczyć sztywności sprężystego zamocowania $\alpha_{\omega}$ (3) i wskaźniki utwierdzenia $\kappa(2)$ dla rozpatrywanego typu i grupy żebrowania. Obliczenia wykonano w arkuszu kalkulacyjnym. 


\section{Numerical validation with FEM - LTBeamN, Abaqus}

LTBeamN (version 1.0.3) is an engineering software tool based on bar finite elements. It allows the determination of critical moments for LTB of beams, single- and multi-span, and also cantilever ones with bisymmetric I-sections. The software makes it possible to adopt classic boundary conditions (fork support or fixity), and to account for the elastic restraint of beams at supports. The results of calculations for an exemplary IPE300 beam with a span of $L=5 \mathrm{~m}$ are shown in Figure 3. The degree of the elastic restraint of the beam at supports corresponds to ribs made from z longitudinally cut circular tube, of type I and group 1 (Ø127.0/10).

\section{Weryfikacja numeryczna z wykorzystaniem MES - LTBeamN, Abaqus}

LTBeamN (ver. 1.0.3) jest programem inżynierskim, opartym na prętowych elementach skończonych. Pozwala wyznaczyć momenty krytyczne zwichrzenia belek (jedno- lub wieloprzęsłowych oraz wspornikowych) o mono- lub bisymetrycznych przekrojach dwuteowych. Pozwala przyjąc klasyczne warunki brzegowe (podparcie ,widełkowe" lub utwierdzenie), jak również uwzględnić sprężyste zamocowanie belek na podporach. Wyniki obliczeń dla przykładowej belki IPE300 o rozpiętości $L=5 \mathrm{~m}$, której stopień sprężystego zamocowania na podporach odpowiada żebrom z podłużnie rozciętych rur typu I grupy 1 (Ø127,0/10), przedstawiono na rysunku 3.
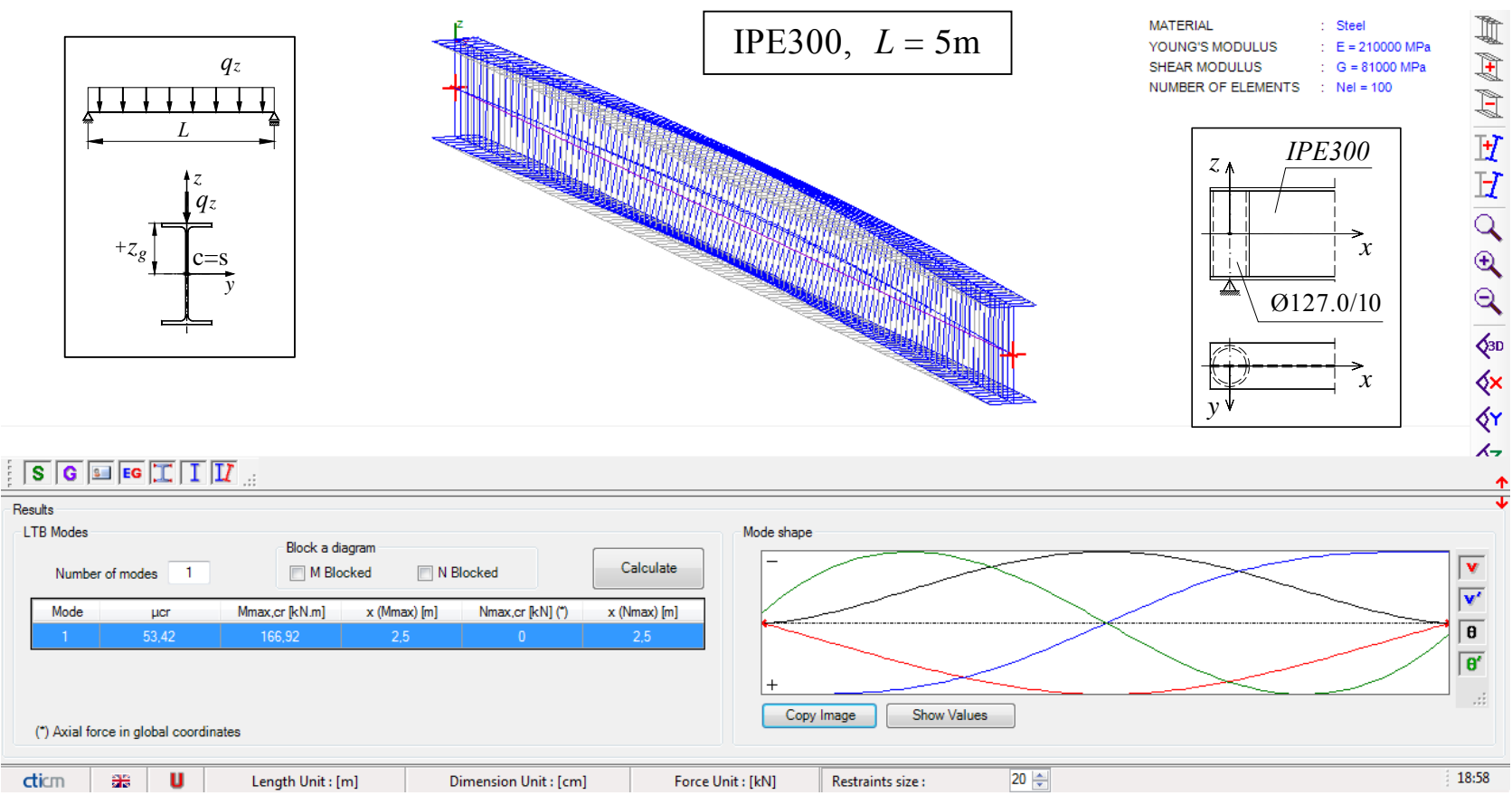

Fig. 3. Exemplary beam (IPE300, $L=5 \mathrm{~m}$, rib Ø127.0/10) modelled using the LTBeamN software Rys. 3. Przykładowa belka (IPE300, L = $5 \mathrm{~m}$, żebro Ø127,0/10) zamodelowana $w$ programie LTBeamN

The calculations of $M_{c r}$ acc. Formula (1) were also validated using Abaqus software. Eight-node continuum elements (C3D8), with six degrees of freedom at the node, were employed. In this case, ribs were modelled physically using the same continuum elements. Beams, together with ribs, were discretized into finite element model with the basic $10 \mathrm{~mm}$ mesh size. Boundary conditions accounted for the restraint of translation of the support sections about major axes of inertia. The load was applied to the top flange of the beam. The computations were run for the elastic range using
Obliczenia $M_{c r}$ wg wzoru (1) zweryfikowano również w programie Abaqus z wykorzystaniem elementów objętościowych (C3D8), ośmiowęzłowych o sześciu stopniach swobody w węźle. W tym przypadku żebra zostały zamodelowane „fizycznie” z wykorzystaniem tych samych elementów objętościowych. Belki wraz z żebrami zdyskretyzowano podstawową siatką MES o oczku $10 \mathrm{~mm}$. Warunki brzegowe uwzględniały blokadę translacji przekrojów podporowych względem głównych osi bezwładności. Obciążenie przyłożono do pasa górnego belki. Obliczenia przeprowadzono w zakresie sprężystym, 


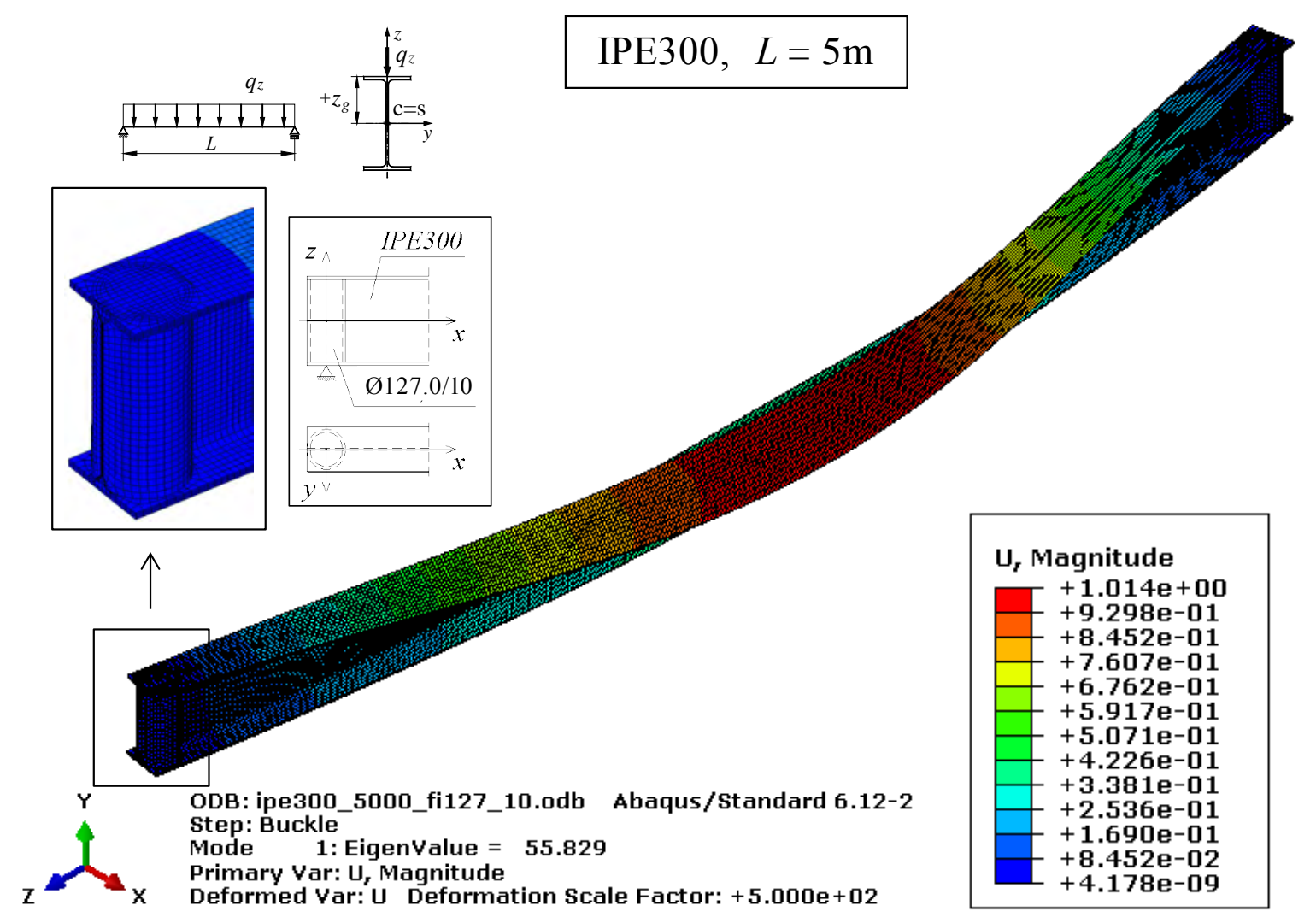

Fig. 4. Exemplary beam (IPE300, $L=5 \mathrm{~m}$, rib Ø127.0/10) modelled using the Abaqus software

Rys. 4. Przykladowa belka (IPE300, $L=5 \mathrm{~m}$, żebro Ø127,0/10) zamodelowana w programie Abaqus

the computational step of the buckling procedure. Figure 4 shows the results of the analysis made with the Abaqus program for the beam shown in Figure 3 (IPE300, $L=5 \mathrm{~m}$, rib Ø127.0/10).

\section{Examples}

The comparative analysis included simply supported steel beams $(E=210 \mathrm{GPa}, G=81 \mathrm{GPa})$, made from shapes: IPE300, HEA300 with spans of $L=5 \mathrm{~m}$ and $7 \mathrm{~m}$, and also IPE500, HEA500 with spans of $L=8 \mathrm{~m}$ and $10 \mathrm{~m}$. The analysis was performed for stiffeners, the characteristics of which are listed in Table 4. Beams were loaded uniformly (Fig. 2), at the level of the top flange $\left(z_{g}=+h / 2\right)$.

Table 5 presents critical moments for beams made from IPE300 and HEA300 shapes with spans of $L=5 \mathrm{~m}$ and $7 \mathrm{~m}$. For the sake of comparison, the values were also given which were obtained for the following support sections: complete warping freedom (FREE, $\kappa=0$ ), end plate with the thickness of $t_{p}$ and complete warping restraint (FIXED, $\kappa=1)$. The results for the basic types and groups of ribs (acc. Table 3) were shaded. z wykorzystaniem kroku obliczeniowego procedury „buckling”. Na rysunku 4 pokazano wyniki analizy w programie Abaqus dla belki według rysunku 3 (IPE300, $L=5$ m, żebro Ø127,0/10).

\section{Przykłady}

Do analizy porównawczej przyjęto swobodnie podparte belki stalowe $(E=210 \mathrm{GPa}, G=81 \mathrm{GPa})$, wykonane $\mathrm{z}$ kształtowników: IPE300, HEA300 o rozpiętościach $L=5 \mathrm{~m} \mathrm{i} 7 \mathrm{~m}$ oraz IPE500, HEA500 o rozpiętościach $L=8 \mathrm{~m}$ i $10 \mathrm{~m}$, dla usztywnień scharakteryzowanych $w$ tabeli 4 . Belki obciążono równomiernie (rys. 2), w poziomie półki górnej $\left(z_{g}=+h / 2\right)$.

$\mathrm{W}$ tabeli 5 zamieszczono momenty krytyczne dla belek wykonanych z kształtowników IPE300 i HEA300 o rozpiętościach $L=5 \mathrm{~m} \mathrm{i} 7 \mathrm{~m}$. W celach porównawczych podano również wartości otrzymane dla pełnej swobody spaczenia (FREE, $\kappa=0$ ), dla blachy czołowej o grubości $t_{p}$ oraz dla pełnej blokady spaczenia (FIXED, $\kappa=1$ ) przekrojów podporowych. Wyniki dla podstawowych typów i grup żebrowania według tabeli 3 zaciemniono. 
Table 5. Comparison of $M_{c r}$ for beams IPE300 and HEA300 with $L=5 \mathrm{~m}$ and $7 \mathrm{~m}$

Tabela 5. Porównanie $M_{c r}$ dla belek IPE300 i HEA300 dla L $=5 \mathrm{~m}$ i $7 \mathrm{~m}$

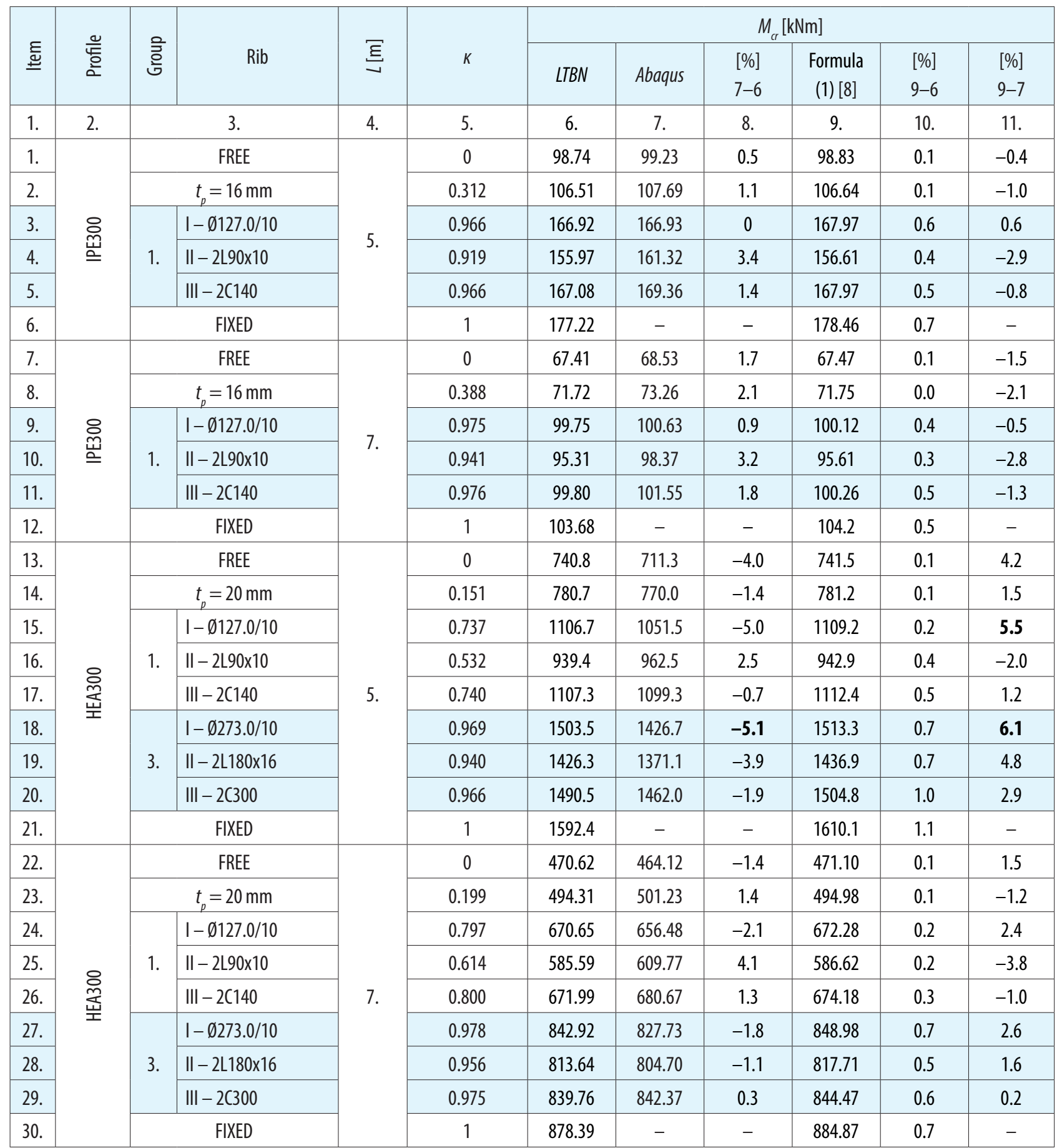

The comparison of values listed in Table 5 indicates that critical moments determined using formula (1) [8] produced very good approximations of the values obtained with LTBeamN software. In the majority of cases, the differences did not exceed $+1 \%$ (Table 5, column 10). When Formula (1) results are compared with those received from numerical analysis performed with Abaqus, the differences ranged as
$\mathrm{Z}$ porównania wartości zamieszczonych $\mathrm{w}$ tabeli 5 wynika, że momenty krytyczne wyznaczone za pomocą wzoru (1) [8] dały bardzo dobre przybliżenie wartości otrzymanych z programu LTBeamN. W znakomitej większości przypadków różnice nie przekroczyły $+1 \%$ (tabela 5 , kolumna 10 ). Natomiast porównując wzór (1) z analizą numeryczną w programie Abaqus, różnice oscylowały pomiędzy: a) dla 
Table 6. Comparison of $M_{c r}$ for beams IPE500 and HEA500 with $L=8 \mathrm{~m}$ and $10 \mathrm{~m}$

Tabela 6. Porównanie $M_{c r}$ dla belek IPE500 i HEA500 dla L $=8 \mathrm{mi} 10 \mathrm{~m}$

\begin{tabular}{|c|c|c|c|c|c|c|c|c|c|c|c|}
\hline \multirow[b]{2}{*}{$\stackrel{\underline{\underline{E}}}{\underline{\underline{\Xi}}}$} & \multirow{2}{*}{ 은 } & \multirow[b]{2}{*}{ 홉 } & \multirow[b]{2}{*}{ Rib } & \multirow[b]{2}{*}{$\underline{\Xi}$} & \multirow[b]{2}{*}{ K } & \multicolumn{6}{|c|}{$M_{c I}[k N m]$} \\
\hline & & & & & & LTBN & Abaqus & $\begin{array}{l}{[\%]} \\
7-6\end{array}$ & $\begin{array}{c}\text { Formula (1) } \\
\text { [8] }\end{array}$ & $\begin{array}{l}{[\%]} \\
9-6\end{array}$ & $\begin{array}{l}{[\%]} \\
9-7\end{array}$ \\
\hline 1. & 2. & & 3. & 4. & 5. & 6. & 7. & 8. & 9. & 10. & 11. \\
\hline 1. & \multirow{9}{*}{$\begin{array}{l}\text { 总 } \\
\text { 至 }\end{array}$} & \multirow{5}{*}{1.} & FREE & \multirow{9}{*}{8.} & 0 & 241.85 & 239.44 & -1.0 & 242.05 & 0.1 & 1.1 \\
\hline 2. & & & $t_{p}=20 \mathrm{~mm}$ & & 0.242 & 254.38 & 253.89 & -0.2 & 254.64 & 0.1 & 0.3 \\
\hline 3. & & & I- $\emptyset 127.0 / 10$ & & 0.883 & 355.77 & 355.35 & 0.1 & 356.69 & 0.3 & 0.4 \\
\hline 4. & & & II - 2L90x10 & & 0.754 & 316.40 & 336.62 & 6.4 & 317.02 & 0.2 & -5.8 \\
\hline 5. & & & III - 2C140 & & 0.885 & 356.28 & 365.12 & 2.5 & 357.50 & 0.3 & -2.1 \\
\hline 6. & & \multirow{3}{*}{2.} & I- $\emptyset 177.8 / 10$ & & 0.957 & 391.34 & 387.59 & -1.0 & 393.20 & 0.5 & 1.4 \\
\hline 7. & & & II - 2L120x10 & & 0.888 & 357.70 & 367.30 & 2.7 & 358.73 & 0.3 & -2.3 \\
\hline 8. & & & III - 2C180 & & 0.942 & 382.87 & 387.73 & 1.3 & 384.54 & 0.4 & -0.8 \\
\hline 9. & & & FIXED & & 1 & 420.27 & - & - & 423.08 & 0.7 & - \\
\hline 10 & \multirow{9}{*}{ 总 } & \multirow{5}{*}{1.} & FREE & \multirow{9}{*}{10.} & 0 & 187.99 & 187.15 & -0.4 & 188.15 & 0.1 & 0.5 \\
\hline 11 & & & $t_{p}=20 \mathrm{~mm}$ & & 0.285 & 196.48 & 197.04 & 0.3 & 196.62 & 0.1 & -0.2 \\
\hline 12 & & & I- $\emptyset 127.0 / 10$ & & 0.904 & 259.58 & 259.53 & 0 & 260.05 & 0.2 & 0.2 \\
\hline 13 & & & II - 2L90x10 & & 0.793 & 236.23 & 249.08 & 5.4 & 236.54 & 0.1 & -5.0 \\
\hline 14 & & & III- $2 C 140$ & & 0.906 & 259.91 & 265.54 & 2.2 & 260.61 & 0.3 & -1.9 \\
\hline 15 & & \multirow{3}{*}{2.} & I- $\emptyset 177.8 / 10$ & & 0.965 & 279.49 & 277.45 & -0.7 & 280.42 & 0.3 & 1.1 \\
\hline 16 & & & II - 2L120x10 & & 0.909 & 260.73 & 266.25 & 2.1 & 261.46 & 0.3 & -1.8 \\
\hline 17 & & & III - 2C180 & & 0.953 & 274.86 & 278.08 & 1.2 & 275.78 & 0.3 & -0.8 \\
\hline 18 & & \multirow{6}{*}{1.} & FIXED & & 1 & 294.88 & - & - & 296.42 & 0.5 & - \\
\hline 19 & \multirow{9}{*}{$\begin{array}{l}\text { 员 } \\
\text { 岌 }\end{array}$} & & FREE & \multirow{9}{*}{8.} & 0 & 1004.3 & 994.0 & -1.0 & 1005.2 & 0.1 & 1.1 \\
\hline 20 & & & $\mathrm{t}_{\mathrm{p}}=25 \mathrm{~mm}$ & & 0.166 & 1045.6 & 1054.0 & 0.8 & 1046.4 & 0.1 & -0.7 \\
\hline 21 & & & I- $\emptyset 127.0 / 10$ & & 0.618 & 1250.7 & 1260.6 & 0.8 & 1253.8 & 0.2 & -0.5 \\
\hline 22 & & & $\|$ - 2L90x10 & & 0.395 & 1124.7 & 1186.4 & 5.5 & 1126.7 & 0.2 & -5.0 \\
\hline 23 & & & III $-2 C 140$ & & 0.621 & 1253.4 & 1302.5 & 3.9 & 1256.0 & 0.2 & -3.6 \\
\hline 24 & & \multirow{3}{*}{3.} & $1-\emptyset 273.0 / 10$ & & 0.948 & 1711.8 & 1688.6 & -1.4 & 1720.2 & 0.5 & 1.9 \\
\hline 25 & & & II-2L180x16 & & 0.900 & 1599.3 & 1625.8 & 1.7 & 1605.8 & 0.4 & -1.2 \\
\hline 26 & & & $I I I-2 C 300$ & & 0.942 & 1694.5 & 1718.0 & 1.4 & 1704.3 & 0.6 & -0.8 \\
\hline 27 & & & FIXED & & 1 & 1869.9 & - & - & 1885.3 & 0.8 & - \\
\hline 28 & \multirow{9}{*}{$\begin{array}{l}\text { 吕 } \\
\text { 产 }\end{array}$} & & FREE & \multirow{9}{*}{10.} & 0 & 769.6 & 771.2 & 0.2 & 770.3 & 0.1 & -0.1 \\
\hline 29 & & & $\mathrm{t}_{\mathrm{p}}=25 \mathrm{~mm}$ & & 0.200 & 798.0 & 813.2 & 1.9 & 798.8 & 0.1 & -1.8 \\
\hline 30 & & & $I-\emptyset 127.0 / 10$ & & 0.669 & 935.0 & 948.9 & 1.5 & 936.0 & 0.1 & -1.4 \\
\hline 31 & & 1. & II - 2L90x10 & & 0.450 & 852.4 & 901.3 & 5.7 & 853.1 & 0.1 & -5.3 \\
\hline 32 & & & III - 2C140 & & 0.672 & 936.3 & 976.1 & 4.3 & 937.5 & 0.1 & -4.0 \\
\hline 33 & & \multirow{3}{*}{3.} & $1-\emptyset 273.0 / 10$ & & 0.958 & 1207.6 & 1203.3 & -0.4 & 1212.7 & 0.4 & 0.8 \\
\hline 34 & & & II-2L180x16 & & 0.918 & 1145.2 & 1168.4 & 2.0 & 1148.3 & 0.3 & -1.7 \\
\hline 35 & & & III - 2C300 & & 0.953 & 1198.6 & 1219.6 & 1.8 & 1203.8 & 0.4 & -1.3 \\
\hline 36 & & & FIXED & & 1 & 1292.3 & - & - & 1300.4 & 0.6 & - \\
\hline
\end{tabular}


follows: a) for IPE300 beams from $-2.9 \%$ to $+0.6 \%$, and b) for HEA300 beams from $-3.8 \%$ to $+6.1 \%$ (Table 5, column 11).

FEM simulations with Abaqus in relation to LTBeamN produced the following differences: a) for IPE300 beams from $+0.5 \%$ to $+3.4 \%$, and b) for HEA300 beams from $-5.1 \%$ to $+4.1 \%$ (Table 5 , column 8 ). The differences in results above $+5 \%$ and below $-5 \%$ were written in bold.

Table 6, on analogous terms as Table 5, presents critical moments for beams made from IPE500 and HEA500 shapes with spans of $L=8 \mathrm{~m}$ and $10 \mathrm{~m}$.

The comparison of the data in Table 6 shows that critical moments determined with Formula (1) [8] were close approximations of the results received by means of LTBeamN. The differences did not exceed $+1 \%$ (Table 6 , column 10 ). The results were also verified using Abaqus (Table 6, column 11). In this case, the differences were as follows: a) for IPE500 beams from $-5.8 \%$ to $+1.4 \%$, and $b$ ) for HEA500 beams from $-5.3 \%$ to $+1.9 \%$. Upon comparing the results of numerical simulations with the use of FEM (Abaqus) with those received by means of LTBeamN (Table 6, column 8), the following difference could be seen: a) for IPE500 beams from $-1.0 \%$ to $+6.4 \%$, and $b$ ) for HEA500 beams from $-1.4 \%$ to $+5.7 \%$. The differences in results above $+5 \%$ and below $-5 \%$ were given in bold.

Table 7 shows percentage increase in $M_{c r}$ (columns 7 and 12) of the analysed beams with closed section ribs relative to fork support (FREE). Columns 8 and 13 provide percentage increase in beam mass depending on the rib type used, when compared with a beam that was not stiffened with ribs.

On the basis of the data in Table 7, the following conclusions can be drawn. Increase in the critical moments of beams made from IPE300 shape (Table 7, rows 3-5), stiffened with ribs of group 1 is up to $+70 \%$ (for type I and III, $L=5 \mathrm{~m}$ ), and up to $+49 \%$ (for type I and III, $L=7 \mathrm{~m}$ ). By contrast, classic end plate $t_{p}=16 \mathrm{~mm}$ produced an increase in $M_{c r}$ which did not exceed $+8 \%$ (row 2 ).

For beams made from HEA300 shape (Table 7), the greatest increase in critical moments, which amounted up to $+104 \%(L=5 \mathrm{~m})$ and $+80 \%(L=$ $7 \mathrm{~m}$ ), was obtained when ribs of type I and group 3, (rows 12-14) were used. When ribs of group 1 (rows 9-11) were applied, $M_{c r}$ increase did not exceed $+50 \%$ (for type I and III, $L=5 \mathrm{~m}$ ), or $+43 \%$ (for type I and III, $L=7 \mathrm{~m}$ ). The lowest increase (up to $+5 \%$ ) was produced by the end plate $t_{p}=20 \mathrm{~mm}$ (row 8 ), despite belek IPE300 od $-2,9 \%$ do $+0,6 \%$ oraz b) dla belek HEA300 od $-3,8 \%$ do $+6,1 \%$ (tabela 5 , kolumna 11 ).

$\mathrm{Z}$ kolei symulacje MES w programie Abaqus w odniesieniu do $L T B e a m N$ dały następujące różnice: a) dla belek IPE300 od $+0,5 \%$ do $+3,4 \%$ oraz b) dla belek HEA300 od $-5,1 \%$ do $+4,1 \%$ (tabela 5 , kolumna 8). Różnice w wynikach powyżej $+5 \%$ lub poniżej $-5 \%$ pogrubiono.

W tabeli 6 (w układzie analogicznym do tabeli 5) zamieszczono momenty krytyczne dla belek wykonanych z kształtowników IPE500 i HEA500 o rozpiętościach $L=8 \mathrm{~m}$ i $10 \mathrm{~m}$.

$\mathrm{Z}$ porównania wartości zamieszczonych $\mathrm{w}$ tabeli 6 wynika, że momenty krytyczne wyznaczone za pomocą wzoru (1) [8] dały bardzo dobre przybliżenie wartości otrzymanych z programu LTBeamN. Różnice nie przekroczyły $+1 \%$ (tabela 6 , kolumna 10$)$. Uzyskane wartości zweryfikowano również w programie Abaqus (tabela 6, kolumna 11). W tym przypadku różnice oscylowały pomiędzy: a) dla belek IPE500 od $-5,8 \%$ do $+1,4 \%$ oraz b) dla belek HEA500 od $-5,3 \%$ do $+1,9 \%$. Porównując z kolei wyniki symulacji numerycznych MES w programie Abaqus z programem LTBeamN (tabela 6, kolumna 8), otrzymano następujące różnice: a) dla belek IPE500 od -1,0\% do $+6,4 \%$ oraz b) dla belek HEA500 od $-1,4 \%$ do $+5,7 \%$. Różnice w wynikach powyżej $+5 \%$ lub poniżej $-5 \%$ pogrubiono.

W tabeli 7 porównano wzrost procentowy $M_{c r}$ (kolumny 7 i 12) analizowanych belek z żebrami zamkniętymi w stosunku do podparcia "widełkowego" (FREE). Natomiast w kolumnach 8 i 13 zamieszczono procentowe zwiększenie masy belki w zależności od zastosowanego sposobu żebrowania w stosunku do belki nieużebrowanej.

$\mathrm{Z}$ porównania wartości zamieszczonych $\mathrm{w}$ tabeli 7 wynikają następujące wnioski. Zwiększenie momentów krytycznych belek wykonanych z kształtownika IPE300 (tabela 7, wiersze 3-5), usztywnionych żebrami grupy 1 , dochodzi do $+70 \%$ (dla typu I i III, $L=5 \mathrm{~m}$ ) oraz do $+49 \%$ (dla typu I i III, $L=7 \mathrm{~m}$ ). Natomiast klasyczna blacha czołowa $t_{p}=16 \mathrm{~mm}$ dała wzrost $M_{c r}$ nieprzekraczający $+8 \%$ (wiersz 2).

Dla belek wykonanych z kształtownika HEA300 (tabela 7) największy wzrost momentów krytycznych, dochodzący do $+104 \%(L=5 \mathrm{~m})$ oraz $+80 \%$ ( $L=7 \mathrm{~m}$ ), dały żebra I typu grupy 3 (wiersze $12-14$ ). Stosując żebra grupy 1 (wiersze 9-11), zwiększenie $M_{c r}$ nie przekraczało $+50 \%$ (dla typu I i III, $L=5 \mathrm{~m}$ ) oraz $+43 \%$ (dla typu I i III, $L=7 \mathrm{~m}$ ). Najniższy wzrost (do $+5 \%$ ), pomimo większej masy w porównaniu 
Table 7. Comparison of the efficiency of the ribs

Tabela 7. Porównanie efektywności zastosowanych żeber

\begin{tabular}{|c|c|c|c|c|c|c|c|c|c|c|c|c|c|}
\hline \multirow[b]{2}{*}{$\stackrel{E}{\Phi}$} & \multirow[b]{2}{*}{$\frac{0}{\frac{0}{c}}$} & \multirow[b]{2}{*}{ 응 } & \multirow[b]{2}{*}{ Rib } & \multirow[b]{2}{*}{ 焉 } & \multirow[b]{2}{*}{ K } & \multicolumn{2}{|c|}{$M_{c r}[\mathrm{kNm}]$} & \multirow[b]{2}{*}{$\begin{array}{c}{[\%]} \\
\text { increase } \\
\text { in beam } \\
\text { mass }\end{array}$} & \multirow[b]{2}{*}{ 焉 } & \multirow[b]{2}{*}{$K$} & \multicolumn{2}{|c|}{$M_{c r}[\mathrm{kNm}]$} & \multirow[b]{2}{*}{$\begin{array}{c}{[\%]} \\
\text { increase } \\
\text { in beam } \\
\text { mass }\end{array}$} \\
\hline & & & & & & $\begin{array}{c}\text { Formula (1) } \\
\text { [8] }\end{array}$ & $\begin{array}{c}{[\%]} \\
\text { increase } \\
\text { in } M_{c r}\end{array}$ & & & & $\begin{array}{c}\text { Formula (1) } \\
\text { [8] }\end{array}$ & $\begin{array}{c}{[\%]} \\
\text { increase } \\
\text { in } M_{c r}\end{array}$ & \\
\hline 1. & 2. & & 3. & 4. & 5. & 6. & 7. & 8. & 9. & 10. & 11. & 12. & 13. \\
\hline 1. & \multirow{6}{*}{$\begin{array}{l}\text { 옴 } \\
\stackrel{m}{0}\end{array}$} & \multirow{5}{*}{1.} & FREE & \multirow{6}{*}{5.} & 0 & 98.83 & - & - & \multirow{6}{*}{7.} & 0 & 67.47 & - & - \\
\hline 2. & & & $=16 \mathrm{~mm}$ & & 0.312 & 106.64 & 8 & 4.7 & & 0.388 & 71.75 & 6 & 3.4 \\
\hline 3. & & & $I-\emptyset 127.0 / 10$ & & 0.966 & 167.97 & 70 & 7.6 & & 0.975 & 100.12 & 48 & 5.5 \\
\hline 4. & & & II - 2L90x10 & & 0.919 & 156.61 & 59 & 7.1 & & 0.941 & 95.61 & 42 & 5.1 \\
\hline 5. & & & III - 2C140 & & 0.966 & 167.97 & 70 & 8.5 & & 0.976 & 100.26 & 49 & 6.0 \\
\hline 6. & & & FIXED & & 1 & 178.46 & 81 & - & & 1 & 104.20 & 54 & - \\
\hline 7. & \multirow{9}{*}{ 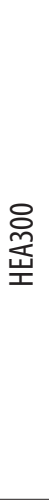 } & \multirow{5}{*}{1.} & FREE & \multirow{9}{*}{5.} & 0 & 741.5 & - & - & \multirow{9}{*}{7.} & 0 & 471.10 & - & - \\
\hline 8. & & & $=20 \mathrm{~mm}$ & & 0.151 & 781.2 & 5 & 5.4 & & 0.199 & 494.98 & 5 & 3.9 \\
\hline 9. & & & $I-\emptyset 127.0 / 10$ & & 0.737 & 1109.2 & 50 & 3.4 & & 0.797 & 672.28 & 43 & 2.5 \\
\hline 10. & & & II - 2L90x10 & & 0.532 & 942.9 & 27 & 3.2 & & 0.614 & 586.62 & 25 & 2.3 \\
\hline 11. & & & III - 2C140 & & 0.740 & 1112.4 & 50 & 3.8 & & 0.800 & 674.18 & 43 & 2.7 \\
\hline 12. & & \multirow{3}{*}{3.} & $1-\emptyset 273.0 / 10$ & & 0.969 & 1513.3 & 104 & 7.7 & & 0.978 & 848.98 & 80 & 5.5 \\
\hline 13. & & & II - 2L180x16 & & 0.940 & 1436.9 & 94 & 10.3 & & 0.956 & 817.71 & 74 & 7.4 \\
\hline 14. & & & III $-2 C 300$ & & 0.966 & 1504.8 & 103 & 11.0 & & 0.975 & 844.47 & 79 & 7.8 \\
\hline 15. & & & FIXED & & 1 & 1610.1 & 117 & - & & 1 & 884.87 & 88 & - \\
\hline 16. & \multirow{9}{*}{$\begin{array}{l}\text { 옴 } \\
\text { 殅 }\end{array}$} & \multirow{5}{*}{1.} & FREE & \multirow{9}{*}{8.} & 0 & 242.05 & 0 & - & & 0 & 188.15 & - & - \\
\hline 17. & & & $=20 \mathrm{~mm}$ & & 0.242 & 254.64 & 5 & 3.8 & & 0.285 & 196.62 & 5 & 3.1 \\
\hline 18. & & & $I-\emptyset 127.0 / 10$ & & 0.883 & 356.69 & 47 & 3.7 & & 0.904 & 260.05 & 38 & 3.0 \\
\hline 19. & & & $\|$ II - 2L90x10 & & 0.754 & 317.02 & 31 & 3.5 & & 0.793 & 236.54 & 26 & 2.8 \\
\hline 20. & & & III $-2 C 140$ & & 0.885 & 357.50 & 48 & 4.1 & 10. & 0.906 & 260.61 & 39 & 3.3 \\
\hline 21. & & & I - Ø177.8/10 & & 0.957 & 393.20 & 62 & 5.3 & & 0.965 & 280.42 & 49 & 4.3 \\
\hline 22. & & 2. & II - 2L120x10 & & 0.888 & 358.73 & 48 & 4.7 & & 0.909 & 261.46 & 39 & 3.8 \\
\hline 23. & & & III $-2 C 180$ & & 0.942 & 384.54 & 59 & 5.7 & & 0.953 & 275.78 & 47 & 4.5 \\
\hline 24. & & & FIXED & & 1 & 423.08 & 75 & - & & 1 & 296.42 & 58 & - \\
\hline 25. & & & FREE & & 0 & 1005.2 & - & - & & 0 & 770.3 & - & - \\
\hline 26. & & & $=25 \mathrm{~mm}$ & & 0.166 & 1046.4 & 4 & 4.0 & & 0.200 & 798.8 & 4 & 3.2 \\
\hline 27. & & & $I-\emptyset 127.0 / 10$ & & 0.618 & 1253.8 & 25 & 2.1 & & 0.669 & 936.0 & 22 & 1.7 \\
\hline 28. & & 1. & II - 2L90x10 & & 0.395 & 1126.7 & 12 & 1.9 & & 0.450 & 853.1 & 11 & 1.5 \\
\hline 29. & 这 & & III $-2 C 140$ & 8. & 0.621 & 1256.0 & 25 & 2.3 & 10. & 0.672 & 937.5 & 22 & 1.8 \\
\hline 30. & & & $1-\emptyset 273.0 / 10$ & & 0.948 & 1720.2 & 71 & 4.6 & & 0.958 & 1212.7 & 57 & 3.7 \\
\hline 31. & & 3. & II - 2L180x16 & & 0.900 & 1605.8 & 60 & 6.2 & & 0.918 & 1148.3 & 49 & 5.0 \\
\hline 32. & & & III $-2 C 300$ & & 0.942 & 1704.3 & 70 & 6.6 & & 0.953 & 1203.8 & 56 & 5.3 \\
\hline 33. & & & FIXED & & 1 & 1885.3 & 88 & - & & 1 & 1300.4 & 69 & - \\
\hline
\end{tabular}


the fact that it has a larger mass compared with ribs of group 1 (columns 8 and 13).

As regards beams from IPE500 shape (Table 7), the most substantial increase in critical moments (up to $+62 \%$ for $L=8 \mathrm{~m}$, and up to $+49 \%$ for $L=10 \mathrm{~m}$ ) was achieved for ribs of type I group 2 (rows 21-23). The use of ribs of group 1 (rows 18-20) enhanced the critical resistance of beams up to $+48 \%$ (for type III, $L=8 \mathrm{~m}$ ) and $+39 \%$ (for type III, $L=10 \mathrm{~m}$ ). By contrast, end plates $t_{p}=20 \mathrm{~mm}$ that gave an increase in the mass of beams comparable with the application of ribs of group 1 (columns 8 and 13), resulted in $M_{c r}$ increase not higher than $+5 \%$ (row 17 ).

The analysis of beams made from HEA500 shape (Table 7) shows that the use of ribs of type I and group 3 (rows 30-32) resulted in the greatest increase in critical moments of beams (up to $+71 \%$ for $L=8 \mathrm{~m}$, and up to $+57 \%$ for $L=10 \mathrm{~m}$ ). Ribs of group 1 (rows 27-29) produced $M_{c r}$ increase of the order of $+25 \%$ (for type I and III, $L=8 \mathrm{~m}$ ), and of $+22 \%$ (for type I and III, $L=10 \mathrm{~m}$ ). When using the end plate $t_{p}=25 \mathrm{~mm}$ that was almost twice as heavy as the ribs of group 1 (columns 8 and 13), only $+4 \%$ increase in critical resistance was obtained (row 26).

\section{Conclusions}

In beams that are prone to LTB, support closed section ribs are used. In the ribs, e.g. acc. group 1,2 and 3, when selecting the geometry of shapes of individual types (I $-\varnothing, \mathrm{II}-2 \mathrm{~L}$, and III $-2 \mathrm{C}$ ) flange widths were accounted for (IPE300, IPE500, HEA300 and HEA500). That produced an increase from $+39 \%$ to $+104 \%$ (Table 7 , columns 7 and 12) in the critical resistance, which results from LTB condition. In contrast, when classic end plates (BL) were employed, for the beams discussed in the paper, increase in $M_{c r}$ was small (from $+4 \%$ to $+8 \%$ ).

The comparison of critical moments in beams with ribs of type I, II and III (Table 7, columns 7 and 12) indicates that ribs of type II made from angles (2L) are the least effective. For the remaining types of stiffeners, i.e. longitudinally cut circular tubes (type I) and channels (type III), the largest $M_{c r}$ increase was observed. Ribs of type I and III gave similar percentage increase in critical moments at comparable increase in the total mass of beams. From the technical and practical standpoint, ribs made of channels offer the most favourable option as they do not need to be cut along the length as is the case with circular tubes.

The highest effectiveness in the restraint of warping (deplanation) of the support section was shown by z żebrami grupy 1 (kolumny 8 i 13), dała blacha czołowa $t_{p}=20 \mathrm{~mm}$ (wiersz 8 ).

W przypadku belek z kształtownika IPE500 (tabela 7) najbardziej efektywne zwiększenie momentów krytycznych (do $+62 \%$ dla $L=8 \mathrm{~m}$ oraz do $+49 \%$ dla $L=10 \mathrm{~m}$ ) uzyskano dla żeber I typu grupy 2 (wiersze 21-23). Zastosowanie żeber grupy 1 (wiersze 18-20) zwiększyło nośność krytyczną belek do $+48 \%$ (dla typu III, $L=8 \mathrm{~m}$ ) oraz $+39 \%$ (dla typu III, $L=10 \mathrm{~m}$ ). Natomiast blachy czołowe $t_{p}=20 \mathrm{~mm}$ zwiększające masę belek porównywalnie $\mathrm{z}$ zastosowaniem żeber grupy 1 (kolumny 8 i 13), dały wzrost $M_{c r}$ nieprzekraczający $+5 \%$ (wiersz 17 ).

Analizując belki wykonane $\mathrm{z}$ kształtownika HEA500 (tabela 7), należy stwierdzić, że zastosowanie żeber I typu grupy 3 (wiersze 30-32) dało największy wzrost momentów krytycznych belek (do $+71 \%$ dla $L=8 \mathrm{~m}$ oraz do $+57 \%$ dla $L=10 \mathrm{~m})$. Żebra grupy 1 (wiersze $27-29$ ) dały wzrost $M_{c r}$ rzędu $+25 \%$ (dla typu I i III, $L=8 \mathrm{~m}$ ) oraz $+22 \%$ (dla typu I i III, $L=10 \mathrm{~m}$ ). Stosując prawie dwukrotnie cięższą blachę czołową $t_{p}=25 \mathrm{~mm}$ w stosunku do żeber grupy 1 (kolumny 8 i 13 ), otrzymano jedynie $+4 \%$ wzrost nośności krytycznej (wiersz 26).

\section{Wnioski}

Zastosowanie w belkach wrażliwych na zwichrzenie żeber podporowych o przekroju zamkniętym, np. według grup 1, 2 i 3, w których geometrię kształtowników poszczególnych typów (I - Ø, II - 2L i III - 2C) dobrano z uwzględnieniem szerokości półek (IPE300, IPE500, HEA300 i HEA500), dało wzrost nośności krytycznej z warunku zwichrzenia od $+39 \%$ do $+104 \%$ (tabela 7 , kolumny 7 i 12). Natomiast wzrost $M_{c r}$ rozpatrywanych w pracy belek z zastosowaniem klasycznych blach czołowych (BL) był nieznaczny (od $+4 \%$ do $+8 \%$ ).

$\mathrm{Z}$ porównania momentów krytycznych belek z żebrowaniem I, II i III typu (tabela 7, kolumny 7 i 12) wynika, że najmniej korzystnie wypadają żebra II typu wykonane z kątowników (2L). Natomiast dla pozostałych typów usztywnień, tzn. podłużnie rozciętych rur (typ I) oraz ceowników (typ III), otrzymano największe wzrosty $M_{c r}$. Żebra typu I i III dały zbliżony procentowy wzrost momentów krytycznych przy porównywalnym zwiększeniu całkowitej masy belek. Z technologicznego i praktycznego punktu widzenia raczej najlepiej wypadają tu żebra z ceowników, których nie trzeba rozcinać na długości jak w przypadku rur.

Największą efektywność w ograniczeniu spaczenia (deplanacji) przekroju podporowego, wynikającą 
HEA300 and HEA500 shapes (Table 7, columns 7 and 12). That results from the widths of flanges and group ("diameter") of closed section ribs. For instance, for beam HEA300, with the span of $L=5 \mathrm{~m}$, stiffened with ribs of group 3 (e.g. of type I and III), increase in $M_{c r}$ was greater than $+100 \%$ when compared with fork support (FREE, $\kappa=0$ ). Additionally, in the case of HEA300 and HEA500 beams, larger "dimeters" of closed section ribs of group 3 produced virtually a double $M_{c r}$ increase compared with ribs of group 1 (Table 7, columns 7 and 12) while the overall increase in beam mass did not exceed $10 \%$ (Table 7 , columns 8 and 13) for a vast majority of cases.

The comparison of beams (Table 7, columns 7 and 12) belonging to the same category of shapes, i.e. IPE300 compared with IPE500, and HEA300 with HEA500, shows that the highest percentage increase in critical moments was found for lower (IPE300 and HEA300) and shorter $(L=5 \mathrm{~m}$ and $7 \mathrm{~m})$ beams. Increase in $M_{c r}$ is directly affected by: a) geometry of the shape (e.g. IPE, HEA), b) type of ribs (e.g. Ø, 2L, $2 \mathrm{C}$ ), and also c) beam span.

In those cases, in which it is necessary to significantly restrain the deplanation of the beam support sections (e.g. when the structure is being stiffened), the use of classic ribs (or end plates) is ineffective and uneconomical when compared with closed section ribs, e.g. those of group 1. Classic ribs, having similar or even greater mass than closed section ribs with small "diameters", produce only a small increase in beam critical resistance (Table 7). Clearly, that does not refer to end plate connections, e.g. beams to columns connections in the frame structure, in which only end plates are found. In this case, end plate connections, which are easy to use in erection, make up for much lower increase in beam critical resistance when compared with closed section ribs.

The use of support closed section ribs in beams prone to LTB considerably confines section warping. In this way, $M_{c r}$ is significantly increased, and hence is design resistance. In the design of beams with such additional stiffeners, when the geometry of the support closed section rib is selected in an adequate way, it is possible to eliminate, almost completely, section deplanation at the site of support (see Table 7, rows 12 and 14).

Additionally, it should be noted that increase in the beam mass concerns almost entirely support sections, which does not lead to the occurrence of any additional span bending moments. z szerokości półki oraz grupy (,średnicy”) zastosowanych żeber zamkniętych, uzyskano dla kształtowników HEA300 oraz HEA500 (tabela 7, kolumny 7 i 12). Na przykład dla belki HEA300, rozpiętości $L=5$ m, usztywnionej żebrami grupy 3 (np. typu I lub III), otrzymano wzrost $M_{c r}$ przekraczający $+100 \%$, w porównaniu z podparciem ,widełkowym” (FREE, $\kappa=0$ ). Ponadto, $\mathrm{w}$ przypadku belek HEA300 i HEA500, większe „średnice” żeber zamkniętych grupy 3 dały praktycznie dwukrotne zwiększenie $M_{c r}$ w porównaniu z żebrami grupy 1 (tabela 7, kolumny 7 i 12), przy czym sumaryczny wzrost masy belki, w znakomitej większości przypadków, nie przekroczył 10\% (Tabela 7, kolumny 8 i 13).

$\mathrm{Z}$ porównania belek (tabela 7 , kolumny 7 i 12), przeprowadzonego $\mathrm{w}$ obrębie danej rodziny kształtowników, tzn. IPE300 z IPE500 oraz HEA300 z HEA500, można stwierdzić, że większe procentowe wzrosty momentów krytycznych otrzymano dla belek niższych (IPE300 i HEA300) oraz krótszych ( $L=5 \mathrm{~m} \mathrm{i} 7 \mathrm{~m}$ ). Na wzrost $M_{c r}$ wpływa bezpośrednio: a) geometria kształtownika (np. IPE, HEA), b) typ żebrowania (np. Ø, 2L, 2C) oraz c) rozpiętość belki.

W przypadku konieczności znacznego ograniczenia deplanacji przekrojów podporowych belki (np. podczas wzmacniania konstrukcji) stosowanie żeber klasycznych (lub blach czołowych) w porównaniu zżebrami zamkniętymi, np. grupy 1 , jest nieekonomiczne i nieefektywne. Żebra takie przy zbliżonej bądź nawet większej masie w stosunku do żeber zamkniętych o niewielkich ,średnicach” dają znikomy wzrost nośności krytycznej belki (tabela 7). Oczywiście nie dotyczy to przypadków połączeń doczołowych, np. belek ze słupami w konstrukcji ramowej, w której występują jedynie blachy czołowe. W tym wypadku uzyskiwana łatwość montażu połączenia doczołowego kompensuje znacznie mniejsze zwiększenie nośności krytycznej belki w stosunku do żeber zamkniętych.

Stosowanie w belkach narażonych na zwichrzenie żeber podporowych o przekroju zamkniętym powoduje znaczne ograniczenie spaczenia przekroju, zwiększając w istotny sposób $M_{c r}$ i ostatecznie nośność obliczeniową. Projektując belki z takim dodatkowym usztywnieniem, przy odpowiednim doborze geometrii zamkniętych żeber podporowych, możliwe jest niemal całkowite wyeliminowanie deplanacji przekroju w miejscu podparcia (por. tabelę 7, wiersze 12 i 14).

Ponadto należy tutaj zwrócić uwagę na fakt, że zwiększenie masy belki dotyczy wyłącznie przekrojów podporowych, co nie powoduje powstania dodatkowych przęsłowych momentów zginających. 
For the beams examined in the study, the use of end plates or classic flexible ribs [9] produced an increase in $M_{c r}$ that did not exceed $+8 \%$.
Natomiast w przypadku zastosowania blach czołowych lub klasycznych żeber podatnych [9] uzyskany, dla analizowanych w pracy belek wzrost $M_{c r}$ nie przekroczył $+8 \%$.

\section{References}

[1] Bijak R., Kowal Z., Malec M., On critical resistance of thin-walled beams stiffened with ribs (in Polish), XXXVIII KN KILiW PAN and KN PZITB, Łódź-Krynica 1992, pp. 13-18.

[2] Giżejowski M., Lateral torsional buckling of steel beams with restrained ability of rotation at the supports (in Polish), „Inżynieria i Budownictwo” 2001, Vol. 10, pp. 589-594.

[3] Gosowski B., Spatial stability of longitudinally and transversely braced solid elements of metal structures (in Polish), Wrocław 1992.

[4] Gosowski B., Non-uniform torsion of stiffened open thin-walled members of steel structures, "Journal of Constructional Steel Research" 2007, Vol. 63, pp. 849-865.

[5] Kowal Z., Malec M., Critical resistance of beams with support closed section ribs (in Polish), „Inżynieria i Budownictwo" 1989, Vol. 2, pp. 71-74.

[6] Pałkowski S., Lateral torsional buckling of I-beams strengthened with end-plates (in Polish), „Inżynieria i Budownictwo" 1997, Vol. 8, pp. 394-395.

[7] Pi Y.-L., Trahair N.S., Distortion and warping at beam supports, "Journal of Structural Engineering” 2000, Vol. 11, pp. 1279-1287.

[8] Piotrowski R., Szychowski A., Lateral-torsional buckling of beams elastically restrained against warping at supports, "Archives of Civil Engineering" 2015, Vol. LXI (4), pp. 155-174.

[9] PN-EN 1993-1-5:2008. Eurocode 3: Design of steel structures. Part 1-5: Plated structural elements, 2008.

\section{Acknowledgments:}

This work was supported by Kielce University of Technology, Grant No. 02.0.04.00/2.01.01.02.0044 MNSC. BKMK.17.004

\section{Podziękowania:}

Praca była finansowana przez Politechnikę Świętokrzyska, grant nr 02.0.04.00/2.01.01.02.0044 MNSC. BKMK.17.004 